\title{
Keeping house: evaluation of housekeeping genes for real-time PCR in the red alga, Bostrychia moritziana (Florideophyceae)
}

\author{
Junbo Shim ${ }^{1}$, Eunyoung Shim ${ }^{1}$, Gwang Hoon Kim ${ }^{1, *}$, Jong Won Han ${ }^{2}$ and Giuseppe \\ C. Zuccarello ${ }^{3}$ \\ ${ }^{1}$ Department of Biology, Kongju National University, Kongju 32588, Korea \\ ${ }^{2}$ National Marine Biodiversity Institute of Korea, Seocheon 33662, Korea \\ ${ }^{3}$ School of Biological Sciences, Victoria University of Wellington, P.O. Box 600, Wellington 6140, New Zealand
}

Biological response of cells to variable conditions should affect the expression level of certain genes. Quantification of these changes in target genes needs stable internal controls. Real-time quantitative polymerase chain reaction (PCR) has traditionally used reference or 'housekeeping' genes, that are considered to maintain equal expression in different conditions, to evaluate changes in target genes between samples and experimental conditions. Recent studies showed that some housekeeping genes may vary considerably in certain biological samples. This has not been evaluated in red algae. In order to identify the optimal internal controls for real-time PCR, we studied the expression of eleven commonly used housekeeping genes; elongation factor 1-alpha, glyceraldehyde-3-phosphate dehydrogenase, $\beta$-actin, polyubiquitin, 30S ribosomal gene, $60 \mathrm{~S}$ ribosomal gene, beta-tubulin, alpha-tubulin, translation initiation factor, ubiquitin-conjugating enzyme, and isocitrate dehydrogenase in different life-history stages of Bostrychia moritziana. Our results suggest that glyceraldehyde-3-phosphate dehydrogenase (GAPDH) and 30S ribosomal gene, have the most stable gene expression levels between the different life history stages (male, female, carposporophyte, and tetrasporophyte), while the other genes are not satisfactory as internal controls. These results suggest that the combinations of GAPDH and 30S would be useful as internal controls to assess expression level changes in genes that may control different physiological processes in this organism or that may change in different life history stages. These results may also be useful in other red algal systems.

Key Words: Bostrychia moritziana; gene expression; geNorm; housekeeping genes; NormFinder; red algae; RT-qPCR; validation

\section{INTRODUCTION}

An increasing number of studies are being conducted into the role of changes in gene expression on the physiology, biology and reproduction of organisms. These gene expression studies often employ real-time quantitative polymerase chain reaction (RT-qPCR). RT-qPCR can also be used to validate other studies, including microarray data and also more frequently RNA-seq data using a mea- sure called RPKM (Mortazavi et al. 2008). While microarray data and RNA-seq cover a large array of genes, RTqPCR is still the gold standard for expression studies of target genes. RT-qPCR relies on an internal PCR standard for which to compare changes in gene expression of target genes between experimental conditions. These standards, so called 'housekeeping' genes or reference genes,
(9) \$ This is an Open Access article distributed under the terms of the Creative Commons Attribution Non-Commercial License (http://creativecommons.org/licenses/by-nc/3.0/) which permits unrestricted non-commercial use, distribution, and reproduction in any medium, provided the original work is properly cited.
Received March 30, 2016, Accepted May 25, 2016

* Corresponding Author

E-mail: ghkim@kongju.ac.kr

Tel: +82-41-850-8504, Fax: +82-41-850-8479 
are from genes that are assumed to be necessary for regular physiological maintenance of the organism, and are considered to not alter during the experimental manipulations or different life history stages. Studies have shown that equal expression of 'standard' housekeeping genes (HKGs) can not be assumed and must be tested for each organism under study (e.g., Ransbotyn and Reusch 2006, Hibbeler et al. 2008, Wu et al. 2013).

Bostrychia moritziana is a red alga and a member of the Florideophyceae. The class Florideophyceae contains approximately $90 \%$ of all described red algal species (Brodie and Zuccarello 2007). Bostrychia has been proposed as a model system for evolutionary studies of red algae (Zuccarello and West 2011). Like many Florideophyceae, Bostrychia has an alternation of generations between haploid gametophytes (separate male and female plants) and morphologically identical free-living diploid sporophytes (tetrasporophyte), that produce spores by meiosis. Like nearly all red algae, Bostrychia has an alternate stage between the gametophytes and the free-living sporophyte, producing what has been called a triphasic red alga life cycle (Saunders and Hommersand 2004). This alternate stage is the carposporophyte, the parasitic development of the zygote on the female plant (Kamiya and Kawai 2002). The genetics of sexual differentiation and transcriptomic difference between the various stages is poorly known in red algae and the genes involved are mostly unexplored (Asamizu et al. 2003, Kamiya et al. 2011). At the proteomic level only $3.7-7.4 \%$ of proteins are differentially expressed in males versus females (Kim et al. 2008). Without an expressed sequence tag (EST) dataset and understanding of gene homology, it is difficult to hypothesize on the function of these proteins.

Transcriptomics is a powerful way to study an array of genes that could be important in various biological process. To find genes that are over- or under-expressed in particular stages, and therefore could be causative, it is critical that a good internal standard is established. These internal standards (HKGs) ideally are expressed at near similar levels in all experimental conditions, so to that changes in expression of target genes can be calibrated for handling errors (normalization). HKGs have been evaluated for the red alga Pyropia yezoensis (Wu et al. 2013) and Chondrus crispus (Kowalczyk et al. 2014) and these two studies suggested different sets of genes for the appropriate normalization of expression. P. yezoensis, in the class Bangiophyceae, shares a common ancestor with $C$. crispus (Floridephyceae) over 1.2 billion years ago (Yoon et al. 2004), it is likely that substantial changes in expression stability have occurred in this time. So what are the appropriate HKGs to use? We undertook the screening of eleven commonly used candidate HKGs in different life history stages of Bostrychia and in an asexual isolate to establish a good candidate gene. These data will add to our understanding on which genes are appropriate within the Florideophyceae for RT-qPCR calibration.

\section{MATERIALS AND METHODS}

\section{Plant materials}

Haploid gametophytes (male and female), females containing carposporophytes and free-living diploid sporophytes of B. moritziana were obtained from the John A. West culture collection (isolate 2746). An asexual isolate that recycles apomictic tetraspores was also grown (isolate 3568-2). Female gametophytes that had several carposporophytes referred to as the carposporophyte was also used. The thalli were maintained in unialgal cultures in IMR medium (West et al. 2001, Klochkova et al. 2006) at $20^{\circ} \mathrm{C}$ in a $16 \mathrm{~h}$ light : $8 \mathrm{~h}$ dark cycle with illumination of $>20$ $\mu \mathrm{mol}$ photons $\mathrm{m}^{-2} \mathrm{~s}^{-1}$ provided by cool-white fluorescent lighting. Plants were harvested and cleaned with IMR medium. After removal of moisture from the samples, they were kept at $-70^{\circ} \mathrm{C}$ until use.

\section{RNA extraction and cDNA synthesis}

Total RNA were isolated from the different life history stages using the RNeasy Plant RNA extraction kit (Qiagen, Gaithersburgh, MD, USA) according to manufacturer's protocol. RNA isolation was performed three times for the plants of each life history stages. Genomic DNA contamination was eliminated by on-column digestion with RNase-free DNase I. RNA quality and concentration were determined using gel electrophoresis and spectrophotometrically. RNA samples with $260 / 280$ ratio from 1.9 to $2.1,260 / 230$ ratio from 2.0-2.5 were used for further analysis. First-strand cDNA was synthesized from $3 \mu \mathrm{g}$ of total RNA using the iScriptTM cDNA synthesis kit (BioRad Laboratories, Hercules, CA, USA) in a final reaction volume of $20 \mu \mathrm{L}$ with random primers following the manufacturer's protocol. All cDNAs were diluted 10 times with autoclaved milli-Q water and stored at $-20^{\circ} \mathrm{C}$ until use.

\section{HKG selection and primers design}

Potential HKGs which are popularly used for RT-qPCR analysis were selected from a $B$. mortiziana transcrip- 
tome database (http://genebank.kongju.ac.kr). Eleven genes were selected: elongation factor 1-alpha $(E F-1 \alpha)$, glyceraldehyde-3-phosphate dehydrogenase (GAPDH), beta-actin $(A C T B)$, polyubiquitin $(P U B), 30$ S ribosomal protein (30S), 60S ribosomal protein (60S), beta-tubulin $(T U B B)$, alpha-tubulin (TUBA), translation initiation factor $(T I F)$, ubiquitin-conjugating enzyme $(U b C E)$, and isocitrate dehydrogenase $(I c d H$ ) (Table 1). Primers for selected genes were designed considering melting temperature and products size using the web-based Primer3 program provided by Bioneer (http://web.bioneer.co.kr/cgi-bin/ primer/primer3.cgi).

\section{qPCR and statistical analysis}

Real-time PCR was performed using iQ SYBR Green supermix (Bio-Rad Laboratories) in a real-time PCR detection system (Bio-Rad CFX96; Bio-Rad Laboratories). cDNA samples were amplified in triplicate from the same RNA preparation. The final reaction volume was $20 \mu \mathrm{L}$ and included $5 \mu \mathrm{L}$ of diluted cDNA, $10 \mu \mathrm{L}$ of iQ SYBR Green supermix and $250 \mathrm{nM}$ of each primers (Table 1). The reaction protocol was first set at $95^{\circ} \mathrm{C}$ for 3 min and then 40 cycles of $95^{\circ} \mathrm{C}$ for $15 \mathrm{~s}$ and $60^{\circ} \mathrm{C}$ for $20 \mathrm{~s}$. For each candidate HKG, the specificity of primers and amplified single product was verified by analyzing the melting curves and gel electrophoresis. The expression of each gene was determined from Cq values (synonym, $\mathrm{Ct}$ value) that corresponds to a number of cycles necessary for the PCR amplification to reach a threshold. Cq variability data in HKG comparisons were expressed as whiskers-box plot for all pooled samples. Selected HKGs were tested for the stability of their expression in different life history stages following a normalization strategy using two different algorithms: geNorm using the geNorm plugin of qbase + program (Vandesompele et al. 2002, Hellemans et al. 2007) and Normfinder (Andersen et al. 2004). The expression stability of all candidate HKGs was evaluated by comparing the differences of observed $\mathrm{Cq}$ values across life-history stages. Pairwise variation $\left(V_{n / n+1}\right)$ was calculated using geNorm. The pairwise variation value $(V)$ shows the optimal number of internal control genes required for accurate normalization (Andersen et al. 2004). If the value $(V)$ is lower than 0.15 it is regarded as reliable gene set.

\section{RESULTS}

The haploid gametophytes and diploid sporophytes of B. moritziana are morphologically identical (isomorphic) in thallus structure except for their reproductive structure (Fig. 1). The basal for selecting HKGs in this study was that they are continuously expressed throughout the entire life cycle of B. moritziana, possess different functions from target genes, and have been used as internal controls in other gene expression studies. We searched our Bostrychia transcriptome library data, and selected 11 HKGs (Table 1). The primers of all the selected HKGs were designed for real-time PCR based on our transcriptome library data (Table 1).

The stability of expression of HKGs in Bostrychia was

Table 1. Primers used for real-time PCR

\begin{tabular}{|c|c|c|c|c|}
\hline Gene symbol & Gene name & Forward primer & Reverse primer & Product \\
\hline$A C T B$ & $\beta$-Actin & ATACCGACTTTGGGCAATCC & CGTTTAGCCTAGTCTCCGCC & 124 \\
\hline$E F-1 \alpha$ & Elongation factor 1 alpha & TCCAAAATCGCTGCTAGTGG & TGGCATGCTCTTTTGCCTAC & 167 \\
\hline$G A P D H$ & $\begin{array}{l}\text { Glyceraldehyde-3-phosphate } \\
\text { dehydrogenase }\end{array}$ & ATGTCAAGATCCGGCGTGTA & GCCGACATTGTTGTGGAGTC & 164 \\
\hline$P U B$ & Polyubiquitin & CTTCAAGTTGCTTACCCGCA & AGTCGACCTTGCATCTCGTG & 192 \\
\hline $30 S$ & 30 S ribosomal protein S8 & CCAGGATTAAGAGTGTACGCAA & TCCTCCTAGCCСТAATTGCC & 129 \\
\hline $60 S$ & 60S ribosomal protein L8 & GCATCAAGAAGAGCGTCAGC & GACCTTCGGCCACTCGTTAC & 140 \\
\hline TUBB & $\beta$-Tubulin & GTTGGGTTGTTACCGACGTG & CCGAAACGGGGAAAATAAAG & 161 \\
\hline TUBA & $\alpha$-Tubulin & CGTCGTTGATGAGGTTCGTC & GCGATCCAGAGCAGTTTCAA & 145 \\
\hline$T I F$ & Translation initiation factor IF-2 & GCTGGGCCTTCGTCTATTGT & TCTTGTTTAGCTTGCTTTTCGTT & 101 \\
\hline$U b C E$ & Ubiquitin-conjugating enzyme & AAGGATGTTAATCGGCCCAC & TGAGGGTGTGCGTCATCTTT & 128 \\
\hline IcdH & Isocitrate dehydrogenase & ATGAGTTCCTCAAGGCCCAC & GTTGTTCACCAGCGCGTACT & 134 \\
\hline
\end{tabular}

The primers were designed using the Primer3.

$\mathrm{PCR}$, polymerase chain reaction. 

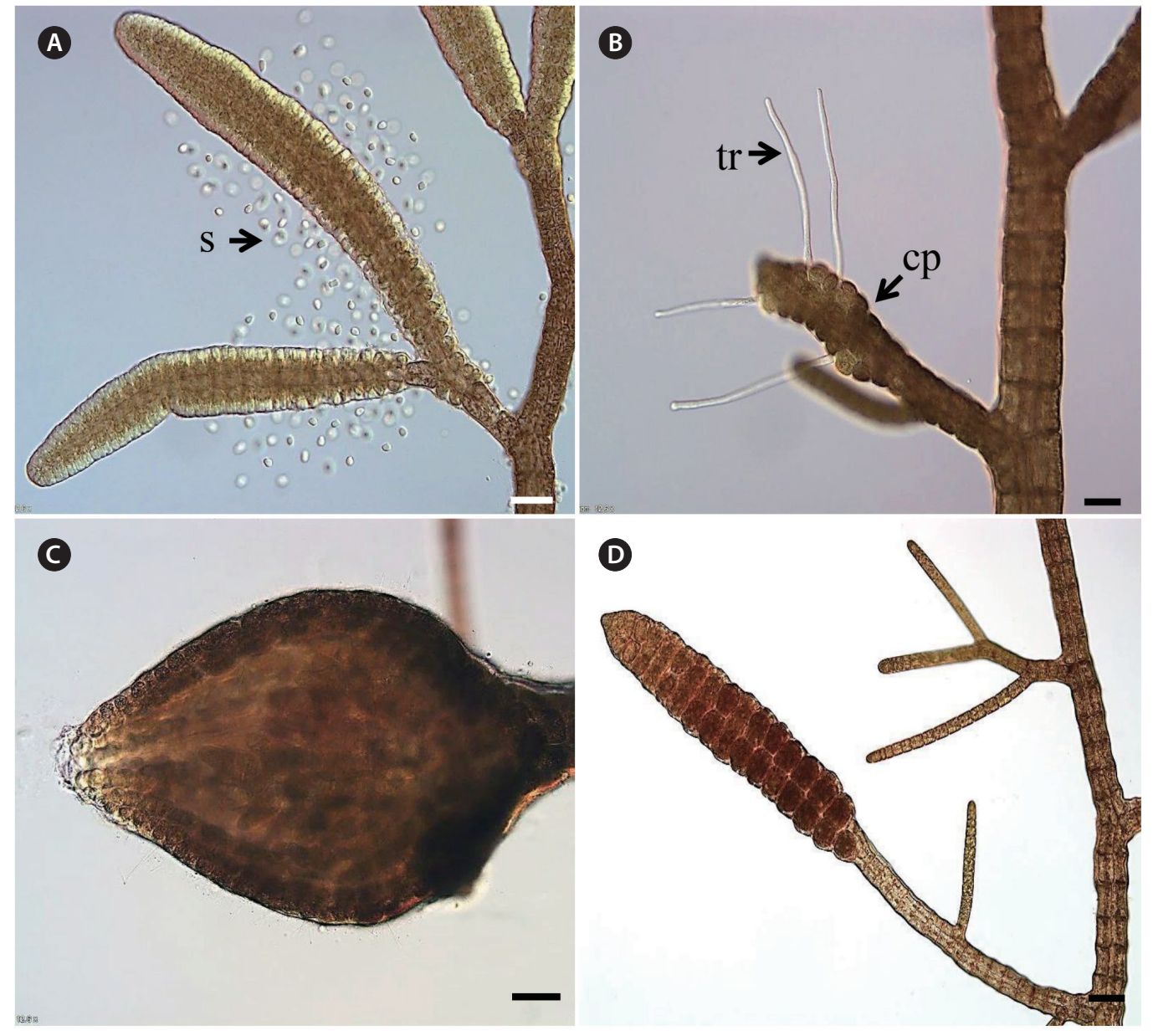

Fig. 1. Morphology of Bostrychia moritziana in different life stages. (A) Male gametophyte with spermatangial branches with released spermatia (s). (B) Female gametophyte with carpogonia (cp, embedded) and trichogynes (tr). (C) Cystocarp (carposporophyte and pericarp) developed on the female thallus. (D) Free-living sporophyte with visible tetrasporangia. Scale bars represent: A-D, $50 \mu \mathrm{m}$.

investigated with Cq values in real-time PCR. Melting curves for each gene were analyzed, all the genes were confirmed to have a single amplification curve. All genes did not generate non-specific products (Appendix 1). The Cq values of each gene showed a value between 19-36 (standard deviation 0.5-2) except for GAPDH, 30S, and $I c d H$ (Fig. 2). We found that $P U B$ showed the highest expression level with a mean Cq value of 20. Conversely, 605 showed the lowest expression level with a mean Cq value of 35 (Fig. 2).

The stability of the gene expression in the different life history stages was analyzed (Fig. 3). Analysis using geNorm showed that GAPDH was the most stable HKG with an $\mathrm{M}$ value of 0.29 , followed by $30 S$ (0.32) and $I c d H(0.35)$ (Fig. 3A). HKGs are regarded as reliable when $M$ values are lower than 0.5 (Vandesompele et al. 2002). Analysis using NormFinder also showed that GAPDH had the most

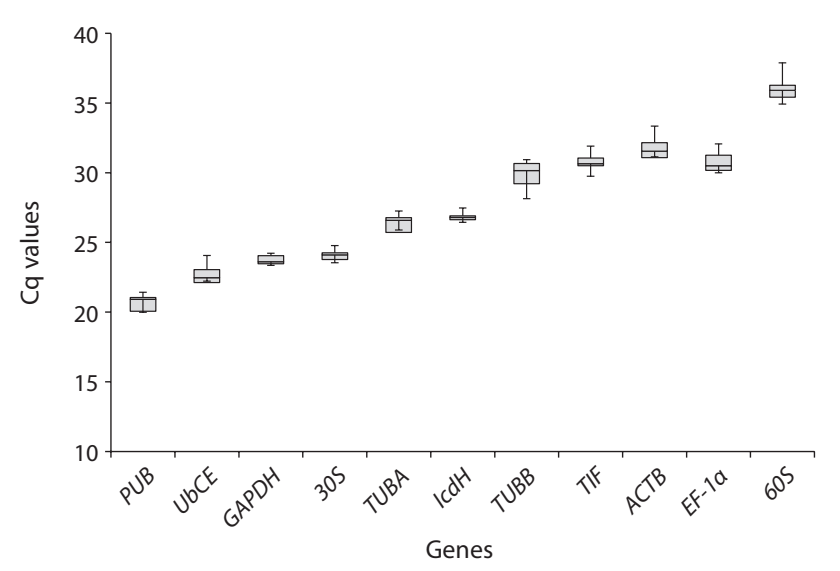

Fig. 2. Range of real-time polymerase chain reaction cycle threshold (Cq) values of 11 candidate housekeeping genes in different life history stages of Bostrychia moritziana. Cq variability in housekeeping gene comparison are shown as median, and $25-75 \%$ range (whiskers) for all samples. 

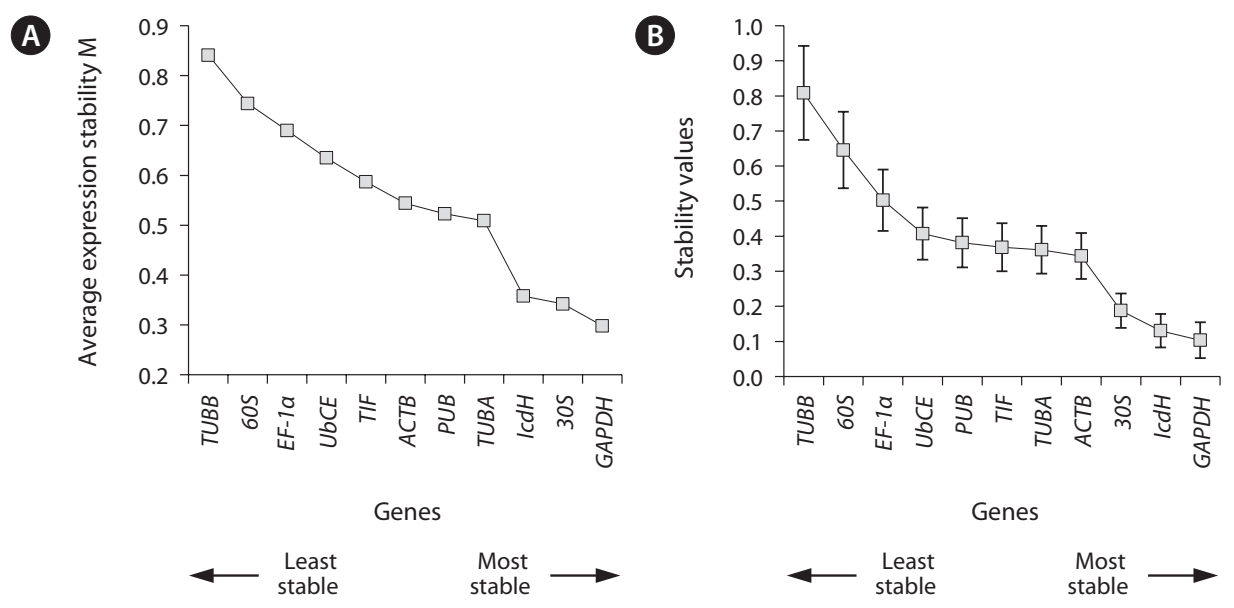

Fig. 3. Gene expression stability (M) and ranks of 11 housekeeping genes as calculated by geNorm (A) and NormFinder (B) programs in all tested samples of different life stages. A lower value indicates a more stable expression pattern.

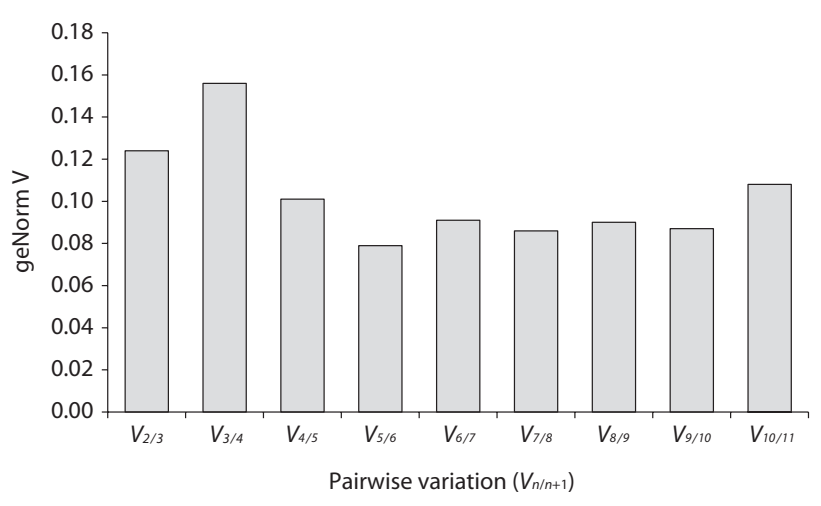

Fig. 4. Determination of optimal number of internal controls for normalization.

stable expression levels between the life history stages followed by 30S (Fig. 3B).

In B. moritziana, our $V$ value ( $V_{2 / 3}$ was 0.124$)$ suggests that a combination of two HKGs is good enough to yield accurate normalization (Fig. 4). These results indicate that the combination of GAPDH and $I c d H$ gives the best gene set for internal control in comparisons between the life history stages of B. moritziana.

\section{DISCUSSION}

The temporal, developmental and physiological pattern of gene expression is a topic that is now amiable to scientific study. Changes in gene expression, even fairly subtle changes, could have significant effects on the physiology of the organism of study (Kim et al. 2016).
To accurately quantify these gene expression changes a stable comparison is needed, to account for variation in RNA quantification and other experimental error. Accurate normalization is an absolute prerequisite for accurate measurements of gene expression changes, yet the determination of these HKGs (reference genes) could be a circular problem as the expression level of these reference genes also needs to be normalized (Hibbeler et al. 2008). The search therefore for genes that are stable over multiple conditions or life history stages is critical and several methods have been established (geNorm in Vandesompele et al. 2002, NormFinder in Andersen et al. 2004). Often normalization procedures to validate candidate genes are not done and HKGs are used that have been used in other organisms or studies, without any validation of their stability in the specific study (Chan et al. 2014). While validation methods are essential to have a stable platform from which changes can be measured between samples, in red algae, few studies have validated HKGs before measuring differences in target genes (e.g., Asamizu et al. 2003 used 60S L3 protein). This could lead to erroneous conclusions on the changes in expression level in target genes. Our results showed that, at least between life history stages of B. moritziana in constant culture conditions, the combination of GAPDH and $30 S$ was the best gene set for this internal control. More than half of the tested HKGs including ACTB and $60 S$ protein were no good for internal controls.

Tests for HKG stability in life history stages of the red alga has recently been performed in P. yezoensis using seven candidate genes (Wu et al. 2013). Their study also showed significant differences in expression of candi- 
date genes. Their conclusion was that GAPDH was the most stable candidate gene. Our study using 11 genes also showed GAPDH as a useful normalization gene (best with geNorm and NormFinder) in comparisons between the life history stages of $B$. mortiziana. Kowalczyk et al. (2014) performed similar validation experiments for HKGs, using C. crispus, monitored the expression of 14 genes in conditions using two sets of samples: cultured samples stressed in laboratory conditions and C. crispus collected on the shore and stressed in situ. Their results showed that translation initiation factor 4A-2 and eukaryotic polypeptide chain release factor 3 were the best normalization genes and GAPDH was one of the worst genes for the internal control in stress-related experiment. Both C. crispus and B. moritziana are members of the class Florideophyceae (subclass Rhodymeniophycidae). These results show the importance of testing reference genes according to the nature of the experiments rather than the evolutionary background of the organism. Our results showed that $I c d H$ and $30 S$ are also pertinent candidates for HKGs in life history study of B. moritziana but previous studies showed that these genes are not stable in other red algae, P. yezoensis and C. crispus (Wu et al. 2013, Kowalczyk et al. 2014).

It is clear from our analysis, and several other studies, that housekeeping genes are not equally expressed and the expression of 'standard' housekeeping genes must be tested for each organism under study. Although RT-qPCR is expensive and time consuming a survey of potential candidate genes at the start of a study would be essential in reducing uncertainty, increasing confidence and may lessen the need for additional experiments to confirm any results.

\section{ACKNOWLEDGEMENTS}

We sincerely thank to Prof. John A. West providing Bostrychia strains. This research was a part of the project titled "Development of selection technique of suitable industrial variety in Korean coast," and part of the project titled "Long-term change of structure and function in marine ecosystems of Korea," funded by the Ministry of Oceans and Fisheries, Korea. This work was also supported by National Marine Biodiversity Institute Research Program (2016M00500). The visit of Dr. Zuccarello to Korea was partially funded by an International Mobility Fund (Minister of Science and Innovation).

\section{REFERENCES}

Andersen, C. L., Jensen, J. L. \& Ørntoft, T. F. 2004. Normalization of real-time quantitative reverse transcription-PCR data: a model-based variance estimation approach to identify genes suited for normalization, applied to bladder and colon cancer data sets. Cancer Res. 64:52455250 .

Asamizu, E., Kato, T., Sato, S., Nakamura, Y., Kaneko, T. \& Tabata, S. 2003. Structural analysis of a Lotus japonicus genome. IV. Sequence features and mapping of seventythree TAC clones which cover the $7.5 \mathrm{Mb}$ regions of the genome. DNA Res. 10:115-122.

Brodie, J. \& Zuccarello, G. C. 2007. Systematics of the species rich algae: red algal classification, phylogeny and speciation. In Hodkinson, T. R. \& Parnell, J. A. N. (Eds.) Reconstructing the Tree of Life: Taxonomy and Systematics of Species Rich Taxa. CRC Press, Boca Raton, FL, pp. 324-334.

Chan, P. -L., Rose, R. J., Abdul Murad, A. M., Zainal, Z., Low, E. -T. L., Ooi, L. C. -L. O., Ooi, S. -E., Yahya, S. \& Singh, R. 2014. Evaluation of reference genes for quantitative realtime PCR in oil palm elite planting materials propagated by tissue culture. PLoS One 9:e99774.

Hellemans, J., Mortier, G., De Paepe, A., Speleman, F. \& Vandesompele, J. 2007. qBase relative quantification framework and software for management and automated analysis of real-time quantitative PCR data. Genome Biol. 8:R19.

Hibbeler, S., Scharsack, J. P. \& Becker, S. 2008. Housekeeping genes for quantitative expression studies in the threespined stickleback Gasterosteus aculeatus. BMC Mol. Biol. 9:18.

Kamiya, M. \& Kawai, H. 2002. Dependence of the carposporophyte on the maternal gametophyte in three ceramiacean algae (Rhodophyta), with respect to carposporophyte development, spore production and germination success. Phycologia 41:107-115.

Kamiya, M., West, J. A. \& Hara, Y. 2011. Induction of apomixis by outcrossing between genetically divergent entities of Caloglossa leprieurii (Ceramiales, Rhodophyta) and evidence of hybrid apomicts in nature. J. Phycol. 47:753762.

Kim, G. H., Han, J. H., Kim, B., Han, J. W., Nam, S. W., Shin, W., Park, J. W. \& Yih, W. 2016. Cryptophyte gene regulation in the kleptoplastidic, karyokleptic ciliate Mesodinium rubrum. Harmful Algae 52:23-33.

Kim, G. H., Shim, J. B., Klochkova, T. A., West, J. A. \& Zuccarello, G. C. 2008. The utility of proteomics in algae taxonomy: Bostrychia radicans/B. moritziana (Rhodomelaceae, 
Rhodophyta) as a model study. J. Phycol. 44:1519-1528.

Klochkova, T. A., Kang, S. -H., Cho, G. Y., Pueschel, C. M., West, J. A. \& Kim, G. H. 2006. Biology of a terrestrial green alga, Chlorococcum sp. (Chlorococcales, Chlorophyta), collected from the Miruksazi stupa in Korea. Phycologia 45:349-358.

Kowalczyk, N., Rousvoal, S., Hervé, C., Boyen, C. \& Collén, J. 2014. RT-qPCR normalization genes in the red alga Chondrus crispus. PLoS One 9:e86574.

Mortazavi, A., Williams, B. A., McCue, K., Schaeffer, L. \&Wold, B. 2008. Mapping and quantifying mammalian transcriptomes by RNA-Seq. Nat. Methods 5:621-628.

Ransbotyn, V. \& Reusch, T. B. H. 2006. Housekeeping gene selection for quantitative real-time PCR assays in the seagrass Zostera marina subjected to heat stress. Limnol. Oceanogr. Methods 4:367-373.

Saunders, G. W. \& Hommersand, M. H. 2004. Assessing red algal supraordinal diversity and taxonomy in the context of contemporary systematic data. Am. J. Bot. 91:14941507.

Vandesompele, J., De Preter, K., Pattyn, F., Poppe, B., Van Roy,
N., De Paepe, A. \& Speleman, F. 2002. Accurate normalization of real-time quantitative RT-PCR data by geometric averaging of multiple internal control genes. Genome Biol. 3:Research0034.

West, J. A., Zuccarello, G. C. \& Kamiya, M. 2001. Reproductive patterns of Caloglossa species (Delesseriaceae, Rhodophyta) from Australia and New Zealand: multiple origins of asexuality in C. leprieurii. Literature review on apomixis, mixed-phase, bisexuality and sexual compatibility. Phycol. Res. 49:183-200.

Wu, X., Huang, A., Xu, M., Wang, C., Jia, Z., Wang, G. \& Niu, J. 2013. Variation of expression levels of seven housekeeping genes at different life-history stages in Porphyra yezoensis. PLoS One 8:e60740.

Yoon, H. S., Hackett, J. D., Ciniglia, C., Pinto, G. \& Bhattacharya, D. 2004. A molecular timeline for the origin of photosynthetic eukaryotes. Mol. Biol. Evol. 21:809-818.

Zuccarello, G. C. \& West, J. A. 2011. Insights into evolution and speciation in the red alga Bostrychia: 15 years of research. Algae 26:21-32. 

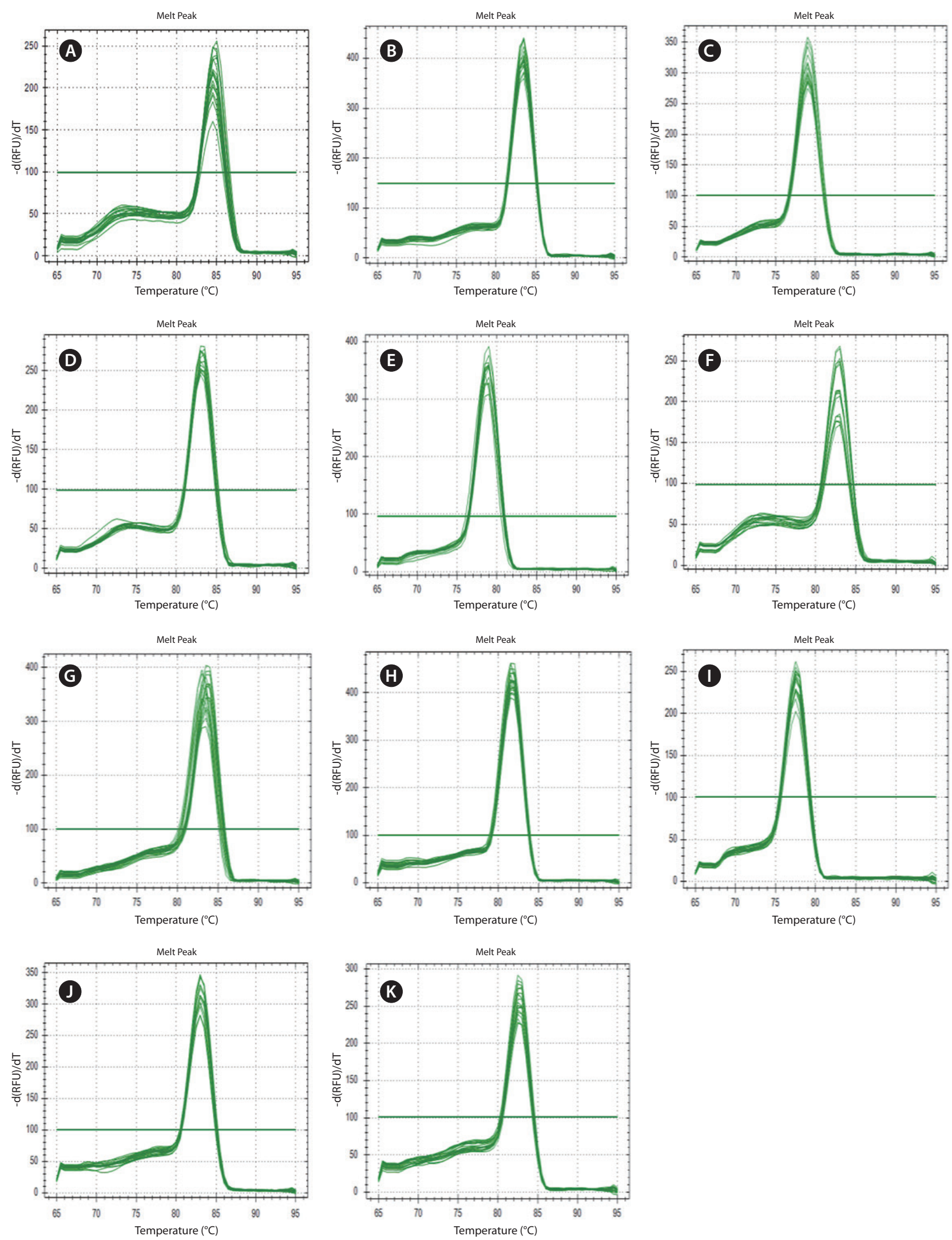

Appendix 1. The melting curve analysis for EF-1a (A), GAPDH (B), ACTB (C), PUB (D), $30 S(\mathrm{E})$, TUBB (F), 60S (G), TUA (H), TIF (I), UbCE (J), and IcdH (K). 